\title{
МЕТОДОЛОГІЧНІ ЗАСАДИ УПРАВЛІННЯ ПРОЦЕСАМИ ФОРМУВАННЯ ТА РЕАЛІЗАЦІЇ БЮДЖЕТНОї ПОЛІТИКИ РОЗВИТКУ ТЕРИТОРІЙ
}

\author{
Пелехатий Андрій Олегович \\ кандидат економічних наук \\ Львівський національний університет імені Івана Франка (м. Львів, Україна) \\ ORSID 0000-0002-3022-852X \\ Pelechatyj_a@i.ua
}

У статті досліджується сукупність теоретичних і методологічних засад управління процесами формування та реалізації бюджетної політики розвитку територій. Розглянуто механізми бюджетної політики розвитку територій. Проаналізовано послідовність формування та реалізації бюджетної політики розвитку територій, яка містить шість етапів: підготовчий, дослідницький, цільовий, функціональний, оцінювальний, підсумковий. Визначено напрями управління процесами розроблення бюджетної політики розвитку територій. Передбачено сукупність заходів, які координують та супроводжують бюджетну політику як на етапі її формування, так і реалізації: стратегічне бюджетне планування, транспарентність бюджетного процесу, стабільність інституційного забезпечення, фінансове стимулювання і санкції, внутрішній контроль інституцій, електронний портал бюджетної системи “Електронний бюджет”, бюджетна децентралізація, бюджетний моніторинг та програмно-цільовий метод (ПЦМ). Запропоновано заходи для удосконалення механізмів управління бюджетними відносинами місцевих органів влади.

Ключові слова: бюджетна політика, розвиток, території, управління, механізми.

DOI: https://doi.org/10.32845/bsnau.2019.3.11

Постановка проблеми. Нагальність вирішення сучасних проблем в економіці потребує подальших наукових досліджень, зокрема у сфері бюджетної політики розвитку територій, а також наближення результатів цих досліджень до реалізації завдань прикладного характеру. Адже ця політика сприяє створенню умов для зростання соціально-економічного потенціалу як окремих адміністративно-територіальних одиниць, так і держави загалом, що може бути досягнуто за умови максимального використання сучасних методів управління.

Аналіз останніх досліджень та публікацій. Проблеми бюджетної політики розвитку територій критично осмислюються у вітчизняних і зарубіжних наукових дослідженнях. Серед фрахівців варто виокремити роботи таких дослідників, як: Г.В. Возняк, В. М. Геєць, В. Г. Дем'янишин, І. О. Луніна, Л. В. Лисяк, Ц. Г. Огонь та інші. Водночас, питання методологічних засад управління процесами формування та реалізації бюджетної політики розвитку територій залишається мало дослідженим.

Метою статті $є$ дослідження питання методологічних засад управління процесами формування та реалізації бюджетної політики розвитку територій.

Виклад основного матеріалу. По відношенню до бюджетної політики розвитку територій під управлінням ми розуміємо системну сукупність теоретичних і методологічних підходів, ідей, принципів або уявлень, спрямованих на визначення перспективних напрямів їх розвитку, основні механізми взаємодії суб'єкта і об'єкта управління, характер взаємовідносин між окремими складовими в процесі формування та реалізації бюджетної політики. Це комплексний процес розробки бюджетної політики розвитку територій та поліпшення взаємодії її суб'єктів з оточуючим середовищем.

Управління процесами формування та реалізації бюджетної політики розвитку територій має в основному передбачати: визначення цілей, напрямків і механізмів їх реалізації; зміни в механізмах бюджетної політики; зміни в чинному законодавстві, що регулюють бюджетні відносини.

Управління процесами формування та реалізації бюджетної політики розвитку територій повинно відповідати певним принципам, до яких слід віднести: системність і комплексність; цілевстановлення та цілереалізація; наукова та методологічна обгрунтованість; збалансованість, ефеективність та соціальна спрямованість; безперервність, довгостроковість, спадковість та послідовність; реалістичність і досяжність; динамічність та гнучкість; наявність зворотного зв'язку; якісна та кількісна визначеність.

Виходячи 3 вищенаведеного, управління розробленням бюджетної політики розвитку територій слід розглядати з позицій процесів вироблення системної сукупності наукових підходів і рішень щодо бюджетної політики на макро- та мезорівнях, реалізація яких спрямована на забезпечення розвитку території у довгостроковому періоді, з визначенням цілей, пріоритетів, якісних, кількісних і часових характеристик, конкретних виконавців та необхідних ресурсів [1].

Значущість управління розробленням бюджетної політики розвитку територій зумовлюється таким.

По-перше, надає можливість пов'язувати поточні бюджетні рішення з майбутніми результатами економічного розвитку територій, а стратегічне осмислення пріоритетів і заходів з їх реалізації - з прогнозуванням їх наслідків.

По-друге, використання даного напряму управління орієнтує на пошук альтернативних варіантів досягнення визначених цілей в межах наявних бюджетних ресурсів, а також політичних, економічних і організаційних обмежень.

По-третє, дозволяє визначати можливості подальшого вдосконалення бюджетної політики, враховувати їх при встановленні цілей та визначенні пріоритетів, формулюванні концепції розвитку території.

По-четверте, дає можливість розподіляти відповідальність між різними а також рівнями влади, за різними напрямками реалізації бюджетної політики, між поточною та перспективною діяльністю.

По-п'яте, існує можливість отримання синергетичного ефекту, який виникає завдяки системному поєднанню чинни- 
ків впливу, принципів, організаційних форм, методів, наукових підходів, економічних та правових механізмів, що мають забезпечувати належний рівень розвитку територій на базі бюджетної політики.

Бюджетна політика розвитку територій реалізується через відповідні механізми, функціональна структура яких, в тому числі, визначається рівнем розвитку фінансових відносин "держава-територія". В контексті даного дослідження, бюджетні механізми - це сукупність адміністративно-управлінських та фінансових методів, форм, стимулів та інструментів формування і використання бюджетних ресурсів з метою досягнення цілей бюджетної політики економічного розвитку територій [2].

Виходячи із економічної сутності бюджетної політики, механізми доцільно детермінувати на: механізми формування доходів, розподілу та використання ресурсів, механізми регулювання міжбюджетних відносин та механізми управління місцевими запозиченнями (табл. 1).

Види механізмів бюджетної політики розвитку територій та їх структура

\begin{tabular}{|c|c|c|c|c|}
\hline $\begin{array}{l}\text { Види / складові } \\
\text { механізмів }\end{array}$ & $\begin{array}{c}\text { Механізми формування } \\
\text { доходів }\end{array}$ & $\begin{array}{l}\text { Механізми розподілу та } \\
\text { використання ресурсів }\end{array}$ & $\begin{array}{l}\text { Механізми регулювання } \\
\text { міжбюджетних відносин }\end{array}$ & $\begin{array}{c}\text { Механізми управління місцевими } \\
\text { запозиченнями }\end{array}$ \\
\hline Методи & $\begin{array}{c}\text { Бюджетне планування, } \\
\text { прогнозування, нормування, } \\
\text { бюджетний контроль }\end{array}$ & \multicolumn{2}{|c|}{$\begin{array}{c}\text { Програмно-цільового бюджетування, цільового } \\
\text { призначення, встановлення порядку та лімітів } \\
\text { використання, дотації, субвенції, вилучені кошти, } \\
\text { бюджетне регулювання, бюджетний контроль }\end{array}$} & $\begin{array}{c}\text { Спостереження та аналіз } \\
\text { бюджетного процесу, } \\
\text { обгрунтування обсягів дефріциту, } \\
\text { джерел погашення, бюджетні } \\
\text { позики на покриття розривів }\end{array}$ \\
\hline Інструменти & $\begin{array}{c}\text { Ставки податків, } \\
\text { обов'язкових зборів та } \\
\text { платежів, нормативи }\end{array}$ & $\begin{array}{l}\text { Бюджетний розпис, } \\
\text { бюджетний секвестр, } \\
\text { бюджетне нормування }\end{array}$ & $\begin{array}{c}\text { Міжбюджетні } \\
\text { трансферти, бюджетні } \\
\text { призначення, бюджетні } \\
\text { зобов'язання, бюджетні } \\
\text { асигнування }\end{array}$ & $\begin{array}{c}\text { Проценті ставки за кредитами, } \\
\text { державними позиками, ставки } \\
\text { доходу за муніципальними } \\
\text { цінними паперами }\end{array}$ \\
\hline Форми & $\begin{array}{c}\text { Податкова / неподаткова } \\
\text { мобілізація надходжень, } \\
\text { доходи від операцій з } \\
\text { капіталом, офріційні } \\
\text { транссрерти }\end{array}$ & \multicolumn{2}{|c|}{$\begin{array}{c}\text { Бюджетне фінансування, бюджетне інвестування, } \\
\text { бюджетне кредитування, бюджетне субсидіювання, } \\
\text { бюджетне дотування, бюджетне резервування }\end{array}$} & $\begin{array}{c}\text { Кредитування, емісія } \\
\text { муніципальних цінних паперів }\end{array}$ \\
\hline Стимули & По & & & $\begin{array}{l}\text { кули; відстро } \\
\text { допомоги }\end{array}$ \\
\hline
\end{tabular}

Ефективна взаємодія складових визначає рівень реалізації бюджетної політики. У практичному сенсі, бюджетні механізми - це добре налагоджена економічна структура, що відображає послідовність та методи дій відповідних державних органів у процесі мобілізації та використання бюджетних коштів. Можна стверджувати, що бюджетні механізми визначають напрями розвитку бюджетної системи $[3,4]$.

Основними принципами функціонування механізмів бюджетної політики розвитку територій є: принцип системності; принцип комплексності; принцип управління; принцип адекватності; принцип функціональної повноти; принцип регламентації; принцип забезпечення ефективності.

Важливими питаннями на нинішній день $є$ не лише формування та розвиток дієвих механізмів бюджетної політики, а й ув'язка з відповідною системою управління. При цьому механізми повинні мати чітко виражений забезпечувальний характер і змінюватися зі зміною бюджетної політики та пріоритетів економічного розвитку.

Ці механізми передбачають комплекс конкретних дій суб'єктів управління бюджетними відносинами шляхом застосування відповідних інструментів, важелів, стимулів, санкцій, методичних засобів та техніки планування, організації, регулювання та контролю. Фактично вони запускають в дію бюджетну політику, призначені для вирішення таких проблем: формування у необхідних обсягах бюджетних ресурсів; їх раціональний розподіл та використання; формування і забезпечення функціонування ефективної взаємодії окремих суб'єктів бюджетної політики.
Далі розглянемо послідовність формування та реалізації бюджетної політики розвитку територій, яка містить шість етапів (рис. 1).

На підготовчому етапі здійснюється вибір горизонту планування, а також та формування систем інформаційного та інституційно-правового забезпечення, яке буде використано у процесі розроблення зазначеної політики. Після цього необхідно визначити ключові пріоритети і стратегічні цілі та завдання соціально-економічного розвитку території, а також обсяги необхідних ресурсів для їх досягнення. При цьому визначається потреба у фінансових ресурсах (як власних, так і позичених) для забезпечення безперебійного фінансування поточних зобов'язань та погашення заборгованості на рівні території.

Другий етап формування та реалізації бюджетної політики розвитку територій - дослідницький. На цьому етапі визначаються сильні і слабкі сторони конкретної адміністративно-територіальної одиниці на основі оцінки впливу факторів зовнішнього і внутрішнього середовища. Також необхідно здійснити ретроспективний аналіз рівня розвитку території та дій органів місцевого самоврядування у його забезпеченні.

На третьому, иільовому етапі, відбувається формування цілей і завдань бюджетної політики розвитку територій, визначення можливих напрямів та механізмів її реалізації.

Четвертий етап формування та реалізації бюджетної політики розвитку територій, функціональний, передбачає розроблення та відбір варіантів політики. На цьому етапі доцільно розробити декілька варіантів та сформувати альтернативні комплекси заходів щодо її втілення. 


\begin{tabular}{|c|c|c|}
\hline \multirow{4}{*}{ 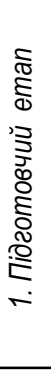 } & $\begin{array}{l}\text { 1.1. Вибір горизонту планування та інституційно- } \\
\text { правового забезпечення }\end{array}$ & \multirow{5}{*}{$\begin{array}{l}\text { 2.1.1. Аналіз сильних і слабких сторін, можливостей і загроз } \\
\text { у БПРТ }\end{array}$} \\
\hline & $\begin{array}{l}\text { 1.2. Визначення пріоритетів соціально- } \\
\text { економічного розвитку території }\end{array}$ & \\
\hline & 1.3. Визначення потреб територій у ресурсах для & \\
\hline & & \\
\hline \multirow{5}{*}{ 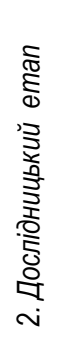 } & \multirow{2}{*}{$\begin{array}{l}\text { 2.1. Здійснення SWOT-аналізу території, чинників } \\
\text { впливу на БПРT }\end{array}$} & \\
\hline & & \multirow{2}{*}{$\begin{array}{l}\text { 1.2.1. Аналіз організації та регламентації бюджетної } \\
\text { політики розвитку територій }\end{array}$} \\
\hline & \multirow[t]{2}{*}{$\begin{array}{l}\text { 2.2. Ретроспективний аналіз рівня розвитку } \\
\text { території та дій ОМС у його забезпеченні }\end{array}$} & \\
\hline & & \multirow{2}{*}{$\begin{array}{l}\text { 1.2.2. Аналіз інформаційно-аналітичного, кадрового, } \\
\text { методичного, технічного забезпечення БПРТ }\end{array}$} \\
\hline & $\begin{array}{l}\text { 2.3. Виявлення проблем у бюджетних відносинах } \\
\text { на рівні території }\end{array}$ & \\
\hline \multirow{3}{*}{ 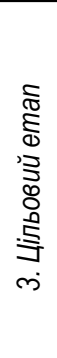 } & $\begin{array}{l}\text { 3.1. Формування цілей і завдань бюджетної } \\
\text { політики розвитку територій }\end{array}$ & $\begin{array}{l}\text { 2.1.1. Визначення базових і допоміжних цілей розвитку } \\
\text { БПРТ }\end{array}$ \\
\hline & $\begin{array}{l}\text { 3.2. Визначення напрямів БПРТ відповідно до } \\
\text { визначених цілей і завдань }\end{array}$ & $\begin{array}{l}\text { 2.2.2. Встановлення зв'язку цілей БПРТ з пріоритетами соц.- } \\
\text { економ. розвитку території }\end{array}$ \\
\hline & $\begin{array}{l}\text { 3.3. Визначення механізмів реалізації бюджетної } \\
\text { політики розвитку територій }\end{array}$ & 2.2.3. Конкретизація цілей в часі \\
\hline \multirow{4}{*}{ 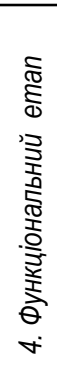 } & 4.1. Формування варіантів БПРТ & 4.1.1. Визначення напрямів БПРТ \\
\hline & 4.2. Аналіз стратегічних альтернатив & 4.1.2. Визначення джерел бюджетних ресурсів \\
\hline & 4.3. Вибір найприйнятнішого варіанту & $\begin{array}{l}\text { 4.1.3. Визначення методів управління бюджетними } \\
\text { ресурсами }\end{array}$ \\
\hline & $\begin{array}{l}\text { 4.4.Деталізація обраного варіанту БПРТ та вибір } \\
\text { оптимальних механізмів реалізації }\end{array}$ & 4.3. Визначення методів управління бюджетними ризиками \\
\hline \multirow{3}{*}{ 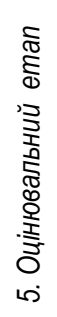 } & $\begin{array}{l}\text { 5.1. Визначення показників і критеріїв ефрективності } \\
\text { БПРТ }\end{array}$ & \multirow[b]{3}{*}{$\begin{array}{l}\text { 5.3.1. Оцінка системи спеціальних критеріїв, які характеризують } \\
\text { параметри і результати досягнення поставлених цілей }\end{array}$} \\
\hline & 5.2. Вибір методів і методології оцінки & \\
\hline & $\begin{array}{l}\text { 5.3. Оцінка та прогнозування ефективності } \\
\text { реалізації програмних рішень }\end{array}$ & \\
\hline \multirow{3}{*}{ 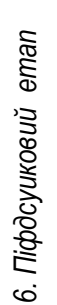 } & $\begin{array}{l}\text { 6.1. Моніторинг бюджетної політики розвитку } \\
\text { територій }\end{array}$ & \\
\hline & 6.2. Виявлення відхилень & \\
\hline & $\begin{array}{l}\text { 4.3. Корегування бюджетної політики розвитку } \\
\text { територій }\end{array}$ & \\
\hline
\end{tabular}

Рис. 1. Послідовність формування та реалізації бюджетної політики розвитку територій (розробка автора) 
Наступний, оцінювальний етап, має розрахунковоаналітичний характер. В межах даного етапу відбувається визначення показників і критеріїв досягнення поставлених цілей, здійснюється вибір методології оцінювання, обґрунтовуються прогнози ефективності реалізації програмних рішень.

Підсумковий етап формування та реалізації бюджетної політики розвитку територій передбачає здійснення постійного моніторингу в ході її реалізації, зокрема з'ясовується відповідність здійснених в межах бюджетної політики заходів загальній стратегії розвитку території за цілями, напрямами та строками реалізації. Зміна умов бюджетної політики розвитку територій потребує постійного моніторингу для успішної її реалізації.

Важливим питанням, яке потребує особливої уваги, $є$ управління процесами розроблення бюджетної політики розвитку територій, а також визначення окремих напрямів його здійснення, що відображено на рис.2.

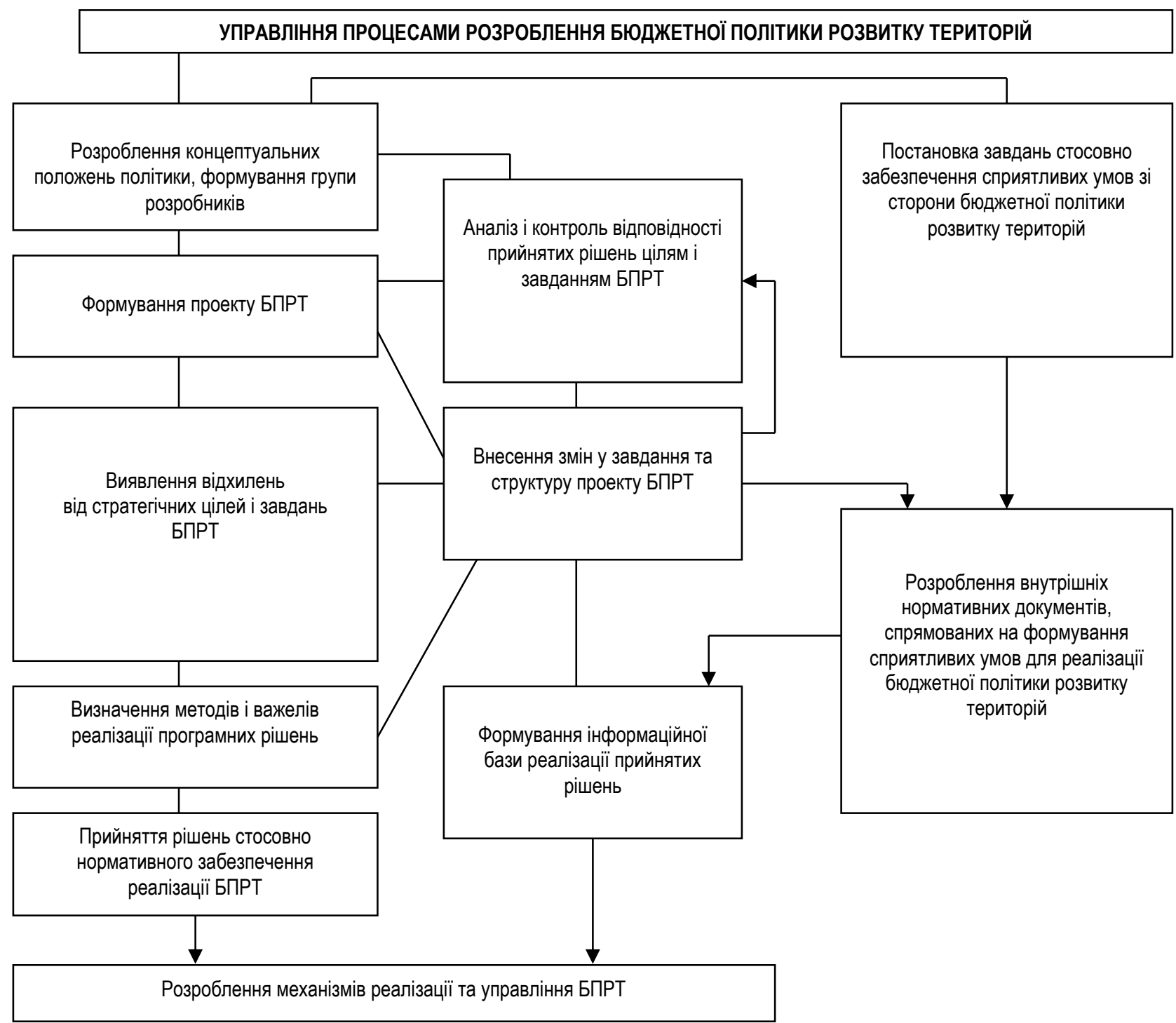

Рис. 2. Напрями управління процесами розроблення бюджетної політики розвитку територій

Перш ніж розпочати розроблення концептуальних положень та фрормування проекту бюджетної політики розвитку територій, необхідно прийняття рішення про створення робочої групи та визначення її складу. Основними функціями такої групи є організація робіт у напрямку вироблення відповідних рішень, забезпечення їх супроводу та доведення до виконавців, здійснення контролю за виконанням поставлених завдань. У склад робочої групи, яка займається розробленням бюджетної політики, здійснює процеси контролю та управління нею, повинні увійти висококваліфіковані фахівці, відповідальні представники органів місцевого самоврядування, які несуть пряму відповідальність за якість визначених завдань та їх виконання. Окрім них до складу робочої групи можуть бути включені представники бізнесу, наукової сфери та громадських організацій. Рішення про створення та склад такої групи повинно прийматися на рівні органу місцевого самоврядування, відповідального за розробку бюджетної політики, і забезпечуватися відповідними повноваженнями. Така робоча група повинна функціонувати впродовж періоду реалізації бюджетної політики, а її результати (як позитивні, так і недоліки та проблеми) повинні стати предметом обговорення не лише на рівні органів місцевого самоврядування, а й безпосередньо її розробників та виконавців.

Загалом управління процесами розроблення бюджетної політики розвитку територій повинно передбачати сукупність конкретних заходів, які координують та супроводжують 
бюджетну політику як на етапі її формування, так і реалізації. До них віднесемо: стратегічне бюджетне планування, транспарентність бюджетного процесу, стабільність інституційного забезпечення, фінансове стимулювання і санкції, внутрішній контроль інституцій, електронний портал бюджетної системи "Електронний бюджет", бюджетна децентралізація, бюджетний моніторинг та програмно-цільовий метод (ПЦМ). Розглянемо їх більш детально.

Першим є стратегічне бюджетне планування, яке передбачає формування головними розпорядниками бюджетних коштів плану своєї діяльності на тривалий період, визначення обсягів необхідних коштів для досягнення поставлених цілей на період від 1 до 15 років. У прикладному аспекті бюджетна політика має бути затверджена належним чином і виглядати як нормативно-правовий акт, який повинен містити інформацію щодо: цілей, завдань, принципів, а також основних напрямів бюджетної політики; макроекономічного прогнозу на довгостроковий період і його впливу на показники о бюджету; аналізу основних ризиків (соціальних, демографрічних, економічних) в умовах реалізації різних варіантів довгострокового прогнозу; аналізу доходів, видатків, дефіциту (профріциту), обсягу заборгованості; прогнозу доходів і видатків бюджету та ін. Основними перевагами стратегічного бюджетного плану є такі: 1) базується на чітко сформульованих цілях і пріоритетах бюджетної політики; 2) дає оцінку відповідності поточної політики та її майбутнього впровадження фіскальній стратегії держави; 3) надає бюджетному процесу риси безперервності й наступності; 4) покращує ефективність розподілу бюджетих ресурсів, підвищуючи прозорість і підзвітність у бюджетному процесі й забезпечуючи механізм систематичного перегляду бюджетних зобов'язань і пріоритетів витрачання бюджетних коштів; 5) може слугувати своєрідним механізмом підвищення взаємодії між різними рівнями публічної влади, заохочуючи різних суб'єктів бюджетних відносин до вищого рівня залученості у бюджетний процес.

Наступним адаптивним заходом в системі управління розробленням бюджетної політики розвитку територій є забезпечення її транспарентності. У сучасних умовах вимоги до забезпечення транспарентності бюджетного процесу повинні відповідати положенням Кодексу належної практики щодо забезпечення прозорості в бюджетно-податковій сфрері Міжнародного валютного фонду. Наразі в Україні при реалізації бюджетного процесу інструмент транспарентності використовується не повною мірою. Зокрема бюджетна інформація не відповідає таким критеріям, як достовірність і зрозумілість. Так, інформація про надходження до бюджетної системи України доходів, надається як оглядова статистичної інформації, без формування детального звіту та без надання документів, що підтверджують дані цифрові показники.

Забезпечення транспарентності бюджетної політики потребує створення єдиної інтегрованої інформаційної системи управління державними фінансами "Електронний бюджет", яка спрямована на забезпечення прозорості, відкритості та підзвітності діяльності органів державної влади і місцевого самоврядування, а також підвищення якості фінансового менеджменту бюджетних організацій. Для досягнення визначеної мети система «Електронний бюджет» повинна забезпечити вирішення цілої низки завдань, зокрема: підвищення доступності інформації про фінансову діяльність та стан адміністративно-територіальних одиниць, про їх активи і зобов'я- зання; забезпечення публікації у відкритому доступі інформації про планові та фрактичні результати діяльності організацій у сфері управління публічними фінансами; забезпечення інтеграції процесів складання і виконання бюджетів, ведення бухгалтерського обліку, а також складання фінансової та іншої звітності. Створення такої інформаційної системи дозволить, по-перше, вирішити питання інформаційної взаємодії бюджетних інституцій, по-друге, здійснювати ефективне управління бюджетними коштами в масштабах всієї країни, потретє, забезпечити прозорість бюджетного процесу.

Управління розробленням бюджетної політики економічного розвитку територій повинно опиратися на інституційну стабільність, яка передбачає можливість реалізації бюджетних планів і програм навіть в умовах негативних змін бюджетного законодавства, оподаткування тощо.

За наявності у своєму розпорядженні значних фрінансових ресурсів, перед місцевими органами влади постає важливе завдання - максимально ефективне їх використання, за умови забезпечення при цьому прямого взаємозв'язку між розподілом коштів і фактичними результатами їх використання відповідно до визначених пріоритетів розвитку громади. Вирішення цього завдання можна досягти при застосуванні програмно-цільового методу - методу управління бюджетними коштами для досягнення конкретних результатів за рахунок коштів бюджету із застосуванням оцінки ефективності використання бюджетних коштів на всіх стадіях бюджетного процесу. Метою його застосування $€$ встановлення безпосереднього зв'язку між виділенням бюджетних коштів та результатами їх використання. Використання програмно-цільового методу дозволяє забезпечити планування бюджету на середньострокову перспективу, перехід від утримання бюджетних установ до надання послуг високої якості населенню, оптимальне використання бюджетних коштів, досягнення в результаті значного економічного і соціального ефекту, підвищення обізнаності громадськості щодо ефективності витрачання коштів бюджету територіальної громади та рівня задоволення споживачів суспільних та гарантованих соціальних послуг.

Важливою складовою управління розробленням бюджетної політики розвитку територій, яка дозволяє своєчасно попередити можливі проблеми, пов'язані з виконанням бюджету, та розробити заходи для покращення якості надання суспільних послуг й підвищення ефективності видатків місцевих бюджетів, $є$ бюджетний моніторинг та оцінка ефективності виконання бюджетних програм. Моніторинг надає можливість на систематичній основі відслідковувати хід виконання програми, результати діяльності розпорядника бюджетних коштів, якість надання бюджетних послуг.Дані, отримані у ході моніторингу, є основою для здійснення оцінки ефективності бюджетної програми, яка передбачає: аналіз відповідності поставлених завдань меті бюджетної програми; аналіз відповідності результативних показників поставленим завданням та меті бюджетної програми; визначення причини неефективного чи недостатньо ефективного виконання бюджетної програми; підготовку пропозицій щодо зміни напрямів спрямування бюджетних коштів з метою досягнення максимального ефекту від їх використання; аналіз доцільності реалізації бюджетної програми в наступних бюджетних періодах або її припинення.

Оцінка ефективності бюджетної програми є ефективним інструментом аналізу, який дозволяє: відійти від практики 
фінансування за принципом утримання бюджетних установ до практики, орієнтованої на забезпечення оптимального співвідношення бюджетних видатків із досягнутими результатами; покращити структуру бюджетної програми як у ході її реалізації (наприклад, уточнивши завдання програми, показники тощо), так і на стадії планування програми на наступний бюджетний період; підвищити прозорість бюджетного процесу шляхом інформування громадськості про результати оцінки бюджетних програм.

Програмно-цільове бюджетування передбачає використання таких інструментів, як фінансове стимулювання і санкції. Поєднання інструментів юридичної відповідальності (цивільної, дисциплінарної, адміністративної або кримінальної) й механізмів заохочення стимулюватиме активність учасників бюджетного процесу. Прикладом заохочень розпорядників бюджетних коштів може стати перерозподіл частини зекономлених фінансових ресурсів тому одержувачу бюджетних коштів, який доклав зусиль до поліпшення їх використання. Створення системи стимулів учасників бюджетного процесу дозволить забезпечити підвищення ефективності бюджетних видатків. Щодо санкцій, то такий інструментарій в Україні розроблений і регламентується положеннями Бюджетного кодексу України.

Що ж стосується внутрішнього контролю, він повинен реалізуватися через спеціально створених у кожній інституції підрозділів внутрішнього контролю, функціями яких мають бути: аудит відповідності діяльності державного органу законодавству, внутрішнім правилам і планам цієї інституції; оцінка економічності, ефективності та результативності використання ресурсів; оцінка відповідності результатів поставленим цілям і завданням, а також превентивна функція. Діяльність таких підрозділів в обов'язковому порядку повинна підлягати контролю з боку вищого органу фінансового контролю.

У рамках управління розробленням бюджетної політики розвитку територій важливе місце належить бюджетній децентралізації, що передбачає плюралізм, відповідальність за власні дії, відхід від бюрократизації структурних та інфраструктурних інституцій, підвищення участі суспільства в прийнятті рішень щодо формування та використання бюджетних коштів тощо. Однак у цьому контексті потрібно згадати і про можливі ризики, адже децентралізація бюджетного процесу у вітчизняних умовах може призвести до розбалансування всієї системи бюджетоутворення в Україні, оскільки залишається висока ймовірність закладання в місцеві бюджети заздалегідь нереальних витрат.
Забезпечення місцевих бюджетів надійними та стабільними джерелами формування доходів потребує від органів місцевого самоврядування та інших органів державної влади невідкладного впровадження системи дієвих заходів, які спрямовані на удосконалення бюджетного та податкового законодавства, що в свою чергу буде сприяти зростанню обсягів промислового виробництва, залученню кредитних ресурсів та інвестицій і в результаті знайде належне відображення у підвищенні рівня питомої ваги власних доходів місцевих бюджетів, а також на фінансово-економічних можливостях місцевої влади.

Місцеві органи влади набувають позиції реально діючих суб'єктів лише за умови реалізації демократичних засад на усіх рівнях державної влади, окрім того необхідно постійно вдосконалювати механізми управління бюджетними відносинами, і саме для цього необхідно вжити наступні заходи [5,6]:

- необхідно постійно зміцнювати ресурсну базу місцевих бюджетів заради забезпечення повноцінної дієздатності органів місцевого самоврядування;

- проводити своєчасне переформатування міжбюджетних відносин, керуючись соціально-економічними показниками та динамікою бюджетних процесів на рівні територій;

- належно підтримувати та впроваджувати інноваційні процеси (важелі, інструменти) у бюджетну систему для реального посилення економічного потенціалу територіальних одиниць;

- коректно формувати і застосовувати заохочення та стимули, щодо нарощування обсягів власних джерел фінансування місцевими органами виконавчої влади та місцевого самоврядування;

- здійснювати повноцінне використання програмно-цільового методу у плануванні та виконанні місцевих бюджетів;

- забезпечити дієвість та ефективність фрінансового контролю на державному, регіональному та місцевому рівняХ.

В умовах адміністративно-територіальної реформи зросла об'єктивна необхідність у розробці та коректуванні довгострокових стратегій розвитку адміністративно-територіальних одиниць, удосконалення програм соціального та економічного розвитку з врахуванням стратегічних пріоритетів. Саме грамотно побудована бюджетна політика у структурі таких стратегій і програм, а також належне управління процесами ії̈ розроблення, дозволить своєчасно та у повному обсязі вирішувати встановлені завдання та проблеми територій.

Список використаної літератури:

1.Бугай Т. Система інституційного забезпечення бюджетного процесу в Україні. Вісник КНТЕУ. 2015. №2. С. 103-118

2.Тимошенко М.В. Тенденції середньострокового бюджетування в країнах ЄС та перспективи застосування в Україні. Ефективна економіка. 2012. №12. Електронний ресурс. Режим доступу: http://www.economy.nayka.com.ua/?op=1\&z=1684

3.Возняк Г. В. Бюджетне вирівнювання: теоретико-методологічні аспекти / Г. В. Возняк // Фінанси України. - 2017. - № 4. - С. 42-54. - Режим доступу: http://nbuv.gov.ua/UJRN/Fu_2017_4_5

4.Возняк Г. В. Регіональний розвиток: сутність і методологічна основа / Г. В. Возняк // Регіональна економіка. - 2015. № 3. - С. 34-43. - Режим доступу: http://nbuv.gov.ua/UJRN/regek_2015_3_6.

5.Пелехатий А.О. Бюджетна політика у забезпеченні розвитку територій: концептуальні домінанти та напрями модернізації: [монографія] / А.О. Пелехатий. Львів: Львівський національний університет імені Івана Франка, 2019. - 386 с.

6.Пелехатий А.О. Обгрунтування нової парадигми бюджетної політики розвитку територій в умовах реформування публічних фрінансів в Україні. Електронне наукове фрахове видання «Ефективна економіка», №7, 2019 [Електронний ресурс]. Ре-

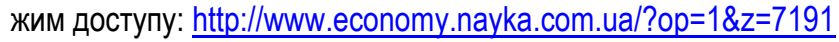

7. Данько, Ю. І. Конкурентні засади сталого розвитку сільських територій. Регіональна економіка, 2017, 3: 70-76.

Вісник Сумського національного аграрного університету

Серія «Економіка і менеджмент», випуск 3 (81), 2019 


\section{References:}

1.Buhai T. (2015). Systema instytutsiinoho zabezpechennia biudzhetnoho protsesu v Ukraini [System of institutional support of the budget process in Ukraine]. Visnyk KNTEU [KNTEU Bulletin]. Vol. 2. pp. 103-118

2.Tymoshenko M.V. (2012). Tendentsii serednostrokovoho biudzhetuvannia v krainakh YeS ta perspektyvy zastosuvannia $v$ Ukraini [Medium-term budgeting trends in EU countries and prospects for application in Ukraine]. Efektyvna ekonomika - Effective Economics, Vol. 12. Retrieved from: http://www.economy.nayka.com.ua/?op=1\&z=1684

3.Vozniak H. V. (2017). Biudzhetne vyrivniuvannia: teoretyko-metodolohichni aspekty [Budgetary equalization: theoretical and methodological aspects]. Finansy Ukrainy - Finance of Ukraine, Vol. 4, pp. 42-54. Retrieved from: http://nbuv.gov.ua/UJRN/Fu_2017_4_5

4. Vozniak H. V. (2015). Rehionalnyi rozvytok: sutnist i metodolohichna osnova [Regional development: essence and methodological basis]. Rehionalna ekonomika - Regional economy, Vol. 3, pp. 34-43. Retrieved from: http://nbuv.gov.ua/UJRN/regek_2015_3_6.

5.Pelekhatyi A.O. (2019). Biudzhetna polityka u zabezpechenni rozvytku terytorii: kontseptualni dominanty ta napriamy modernizatsii [Budget Policy in Territorial Development: Conceptual Dominants and Directions for Modernization]. Lviv: Lvivskyi natsionalnyi universytet imeni Ivana Franka, 386 p. [in Ukrainian].

6.Pelekhatyi A.O. Obhruntuvannia novoi paradyhmy biudzhetnoi polityky rozvytku terytorii v umovakh reformuvannia publichnykh finansiv v Ukraini [Substantiation of the new paradigm of budgetary policy of territorial development in the context of public finance reform in Ukraine]. Efektyvna ekonomika - Effective Economics, №7. Retrieved from: http://www.economy.nayka.com.ua/?op=1\&z=7191. [in Ukrainian].

Pelekhatyy A., PhD, Ivan Franko National University of Lviv (Lviv, Ukraine) of areas

Methodological principles for managing the formation and implementation of a budgetary policy for the development

The article explores the set of theoretical and methodological foundations for managing the processes of formation and implementation of the budget policy of territorial development. The mechanisms of the budgetary policy of territorial development (responding to the solution of strategic and tactical tasks) are considered. The sequence of formation and implementation of the budget policy of territorial development is analyzed, which contains six stages: preparatory (the choice of planning horizon, formation of systems of information and institutional legal support; determination of priorities of socio-economic development of territories and their needs for resources), research (carried out by SWOT- analysis of the territory, retrospective analysis of the level of development of the territory, identified problems in the budgetary relations at the level of the territory), targeted (goals and objectives are formed budget policy, development directions and implementation mechanisms are defined), functional (formation of BPT options, analysis of strategic alternatives, selection of the most suitable options and detail of the selected option), evaluation (determination of indicators and performance criteria of BPT, selection of methods and methodologies of evaluation, evaluation and forecasting of effectiveness implementation of software solutions), final (monitoring, detection of deviations and their correction). The directions of management of processes of development of the budgetary policy of development of territories are defined. There is a set of measures that coordinate and accompany the budget policy both at the stage of its formation and implementation: strategic budget planning, transparency of the budget process, stability of institutional support, financial incentives and sanctions, internal control of institutions, electronic portal of the budget system "Electronic Budget", budget decentralization, budget monitoring, and programmatic targeting (PCM). Measures have been proposed to improve the mechanisms for managing the budgetary relations of local authorities.

Key words: budget policy, development, territories, management, mechanisms.

Дата надходження до редакції: 21.08.2019 р. 